\title{
Insulin-like growth factor-I gene therapy reverses morphologic changes and reduces hyperprolactinemia in experimental rat prolactinomas
}

\author{
Gloria M Console*1, Claudia B Herenu ${ }^{2}$, Gisela A Camihort ${ }^{1}$, \\ Georgina C Luna ${ }^{1}$, Maria I Bracamonte ${ }^{1}$, Gustavo R Morel ${ }^{2}$ and \\ Rodolfo G Goya*2
}

Address: ${ }^{1}$ Department of Cytology, Histology \& Embryology B-CICBA, National University of La Plata, CC455; (1900) La Plata, Argentina and 2INIBIOLP, Faculty of Medicine, National University of La Plata, CC455; (1900) La Plata, Argentina

Email: Gloria M Console* - gconsole2@gmail.com; Claudia B Herenu - c_herenu@yahoo.com; Gisela A Camihort - hdelzotto@yahoo.com.ar; Georgina C Luna -geolu@yahoo.com.ar; Maria I Bracamonte - zulema@netverk.com.ar; Gustavo R Morel - gustavmorel@hotmail.com; Rodolfo G Goya* - rgoya@netverk.com.ar

* Corresponding authors

Published: 25 January 2008

Molecular Cancer 2008, 7:13 doi:10.1186/1476-4598-7-13
Received: 15 September 2007

Accepted: 25 January 2008

This article is available from: http://www.molecular-cancer.com/content/7/I/I3

(C) 2008 Console et al; licensee BioMed Central Ltd.

This is an Open Access article distributed under the terms of the Creative Commons Attribution License (http://creativecommons.org/licenses/by/2.0), which permits unrestricted use, distribution, and reproduction in any medium, provided the original work is properly cited.

\begin{abstract}
Background: The implementation of gene therapy for the treatment of pituitary tumors emerges as a promising complement to surgery and may have distinct advantages over radiotherapy for this type of tumors. Up to now, suicide gene therapy has been the main experimental approach explored to treat experimental pituitary tumors. In the present study we assessed the effectiveness of insulin-like growth factor I (IGF-I) gene therapy for the treatment of estrogen-induced prolactinomas in rats.

Results: Female Sprague Dawley rats were subcutaneously implanted with silastic capsules filled with 17- $\beta$ estradiol $\left(E_{2}\right)$ in order to induce pituitary prolactinomas. Blood samples were taken at regular intervals in order to measure serum prolactin (PRL). As expected, serum PRL increased progressively and 23 days after implanting the $E_{2}$ capsules (Experimental day 0 ), circulating PRL had undergone a 3-4 fold increase. On Experimental day 0 part of the $E_{2}$-implanted animals received a bilateral intrapituitary injection of either an adenoviral vector expressing the gene for rat IGF-I (RAd-IGFI), or a vector (RAd-GFP) expressing the gene for green fluorescent protein (GFP). Seven days post vector injection all animals were sacrificed and their pituitaries morphometrically analyzed to evaluate changes in the lactotroph population. RAd-IGFI but not RAd-GFP, induced a significant fall in serum PRL. Furthermore, RAd-IGFI but not RAd-GFP significantly reversed the increase in lactotroph size (CS) and volume density (VD) induced by $E_{2}$ treatment.
\end{abstract}

Conclusion: We conclude that IGF-I gene therapy constitutes a potentially useful intervention for the treatment of prolactinomas and that bioactive peptide gene delivery may open novel therapeutic avenues for the treatment of pituitary tumors. 


\section{Background}

Pituitary adenomas constitute the most frequent neuroendocrine pathology in humans, comprising up to $15 \%$ of primary intracranial tumors [1] and also are the most prevalent pathology in old female rats [2]. In both species, prolactinomas are the most frequent type of pituitary adenoma.

Estrogen exposure has been linked to the formation of prolactinomas in both humans and animals [3-5]. Estrogens, particularly estradiol and diethylstilbestrol, have been shown to induce lactotropic cell tumors within 2-4 weeks in female rats. Women taking oral contraceptives often display increased prolactin (PRL) levels and have increased incidence of prolactinomas, although not all women appear to be equally susceptible to the mitogenic effect of estradiol [6,7].

There are a number of growth factors that are estrogendependent and function in lactotropic proliferation, differentiation, and/or transformation. The relatedness of these factors and the significance of each alone are not well-understood. Some of these estrogen-regulated factors are epidermal growth factor (EGF), platelet-derived growth factor (PDGF), transforming growth factor alpha (TGF- $\alpha$ ), basic fibroblast growth factor (bFGF), interleukin-2 (IL-2), IL-6, fibroblast growth factor-4 (FGF-4), transforming growth factor- $\beta$ (TGF- $\beta$ ), insulin-like growth factor-I (IGF-I) and IGFI-II [8,9]. Although estrogen is known to up-regulate IGF-I mRNA in normal rat pituitaries [10], large estrogen-induced pituitary adenomas have been reported to possess decreased levels of IGF-I mRNA. Furthermore, partial remission induced by the anti-estrogen tamoxifen was associated with an increase in the pituitary content of IGF-I mRNA of these adenomas [11]. Also, it has been shown that in primary cultures of rat lactotrophs, estrogen has an antiproliferative action in the presence of insulin or IGF-I $[12,13]$. In view of this evidence, it was of interest to determine whether in vivo overexpression of the gene for rat IGF-I in estrogen-induced rat prolactinomas could be able to restore lacotropic cell morphology and reverse hyperprolactinemia. The present report describes our findings.

\section{Results \\ Effect of IGF-I gene therapy on pituitary lactotroph morphology}

Stereotaxic injection of RAd-GFP (an adenoviral vector expressing a chimeric variant of green fluorescent protein; see Methods) into pituitary adenomas induced a significant expression of GFP around the track of the needle (Fig. 1) without significantly damaging the gland (Fig. 1, inset). As expected, three weeks of estrogen treatment induced a significant increase in pituitary size (data not shown) as well as clear changes in the lactotropic cell population, already evident when pituitary sections were qualitatively assessed (Fig 2). Estrogen-induced pituitary adenomas showed a significant $(\mathrm{p}<0.01)$ increase in lactotropic cell size as compared with their intact counterparts (Fig. 3; also see Fig. 2). Seven days of IGF-I gene therapy significantly reversed this change $(\mathrm{p}<0.01)$ although lactotroph cell surface (CS) was still higher than in intact animals (Fig. 3; also see Fig. 2). Lactotroph volume density (VD) was higher in estrogen-induced pituitary adenomas when compared with the pituitaries of intact animals (Fig. 4). Again, IGF-I gene therapy significantly $(\mathrm{p}<0.05)$ reversed this alteration although lactotroph VD in RAd-IGF-I injected adenomas remained higher than in normal intact glands (Fig. 4).

\section{Effect of intrapituitary tumor IGF-I gene therapy on serum PRL levels}

As expected, estrogen administration induced a marked hyperprolactinemia in the animals. Seven days after stereotaxic intrapituitary injection of RAd-IGF-I but not RAdGFP, a significant fall in serum PRL occurred in the estrogen-treated rats (Fig. 5). Nevertheless, serum PRL of the RAd-IGF-I-treated rats remained higher than in the intact rats.

\section{Discussion}

Current therapies for pituitary tumors include surgery and radiotherapy, as well as pharmacological approaches for some types and, although important advances have been made in the treatment of pituitary tumors with these strategies, a fully satisfactory therapy is not yet available [14]. In this context, gene therapy appears as a potentially useful alternative for the treatment of pituitary tumors.

Early studies showed that a herpes simplex virus type-1 (HSV1)-derived vector was highly effective in vivo for gene transfer in rat pituitary prolactinomas [15]. An adenoviral vector, RadTK, harboring the HSV-1 thymidine kinase (TK) suicide gene under the control of the human cytomegalovirus (hCMV) promoter, was used to transfer the TK gene to $\mathrm{GH}_{3}$ and $\mathrm{AtT}_{20}$ rodent pituitary tumor cells. Incubation of RadTK-treated $\mathrm{GH}_{3}$ and $\mathrm{AtT}_{20}$ cells with the prodrug ganciclovir (which after phosphorylation by viral TK becomes toxic) caused ample destruction of the cultures [16]. In the same study, estrogen/sulpiride-induced rat prolactinomas were stereotaxically injected with the same RadTK. Subsequent injection of the host animals with two daily intrapituitary doses of $25 \mathrm{mg}$ ganciclovir/ $\mathrm{kg}$ for 7 days succeeded in partially reducing tumor size and serum PRL levels. Another type of gene therapy strategy for the treatment of pituitary cancer is that based on the transfer of a gene(s) with the ability to rescue the normal phenotype of tumor cells. This approach has been implemented in mice heterozygous for the retinoblastoma (RB) tumor suppressor gene $\left(\mathrm{Rb}^{+/-}\right.$mice) which develop and succumb 


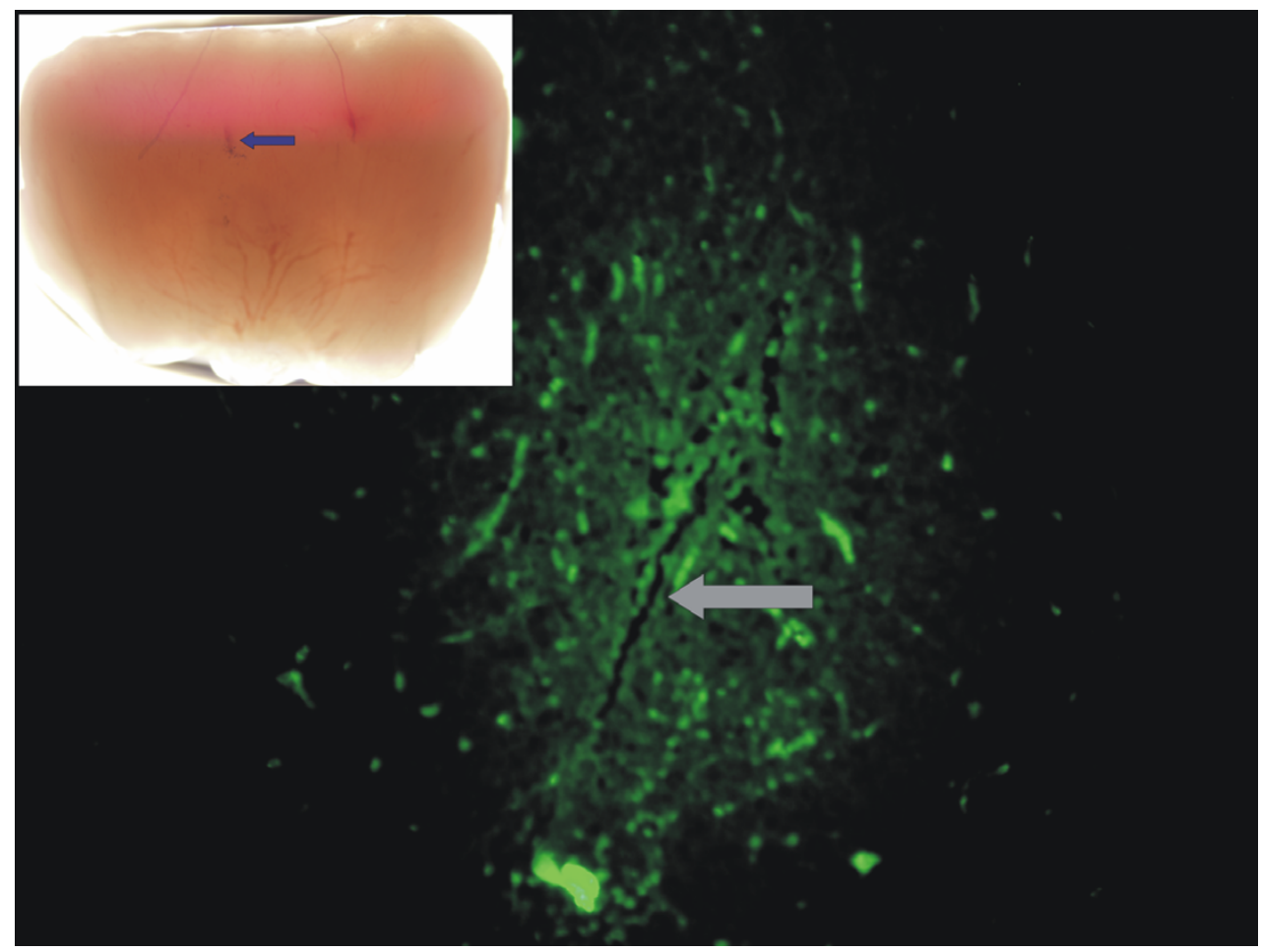

\section{Figure I}

Expression of transgenic GFP/TK in a pituitary adenoma. The main panel shows the green fluorescence of transduced cells around the entry point (arrow) of the needle used to stereotaxically deliver RAd-GFP/TK into the tumor Obj. $\times 20$. The inset shows a low magnification view of the same pituitary adenoma where an entry point of the needle can be seen (arrow). No structural damage is evident as a consequence of the injection. Obj. $\times 4$.

to characteristic pituitary intermediate lobe melanotroph tumors [17]. Intracranial delivery of an adenoviral vector harboring the human RB cDNA to mice carrying actively growing melanotrophic tumors significantly reduced tumor growth and prolonged animal survival [18].

The present study is the first to implement effective pituitary tumor gene therapy using the gene for a bioactive peptide. Within the time frame used, the treatment seems to act mainly on PRL cell size and secretory activity rather than on PRL cell density (CD, data not shown). Our results are consistent with the above mentioned reports documenting that large estrogen-induced pituitary adenomas possess decreased pituitary levels of IGF-I mRNA and that the anti-estrogen tamoxifen increased the IGF-I mRNA content in the involuting adenomas [11]. Our results are also consistent with the evidence that in rat lactotrophs, estrogen has an antiproliferative action in the presence of insulin or IGF-I [12,13]. Furthermore, our data showing that IGF-I gene therapy reduces PRL secretion in estrogen-induced prolactinomas are in line with an early study in rat pituitary cells reporting that IGF-I inhibited the estrogen induced rise in PRL and lactotroph pituitary transcription factor-1 (Pit-1) mRNA levels in females. This study also documented that the inhibitory effect of IGF-I on estrogen-induced PRL and lactotroph Pit-1 mRNA levels did not occur in male pituitary cells [19].

The mechanism by which pituitary overexpression of IGFI reduces lactotropic cell size and inhibits PRL secretion is not clear. Although estrogen is known to increase pituitary expression of IGF-I mRNA, it also increases the expression of IGF binding protein 2 (IGF-BP2) mRNA [10]. Since our approach involves pituitary overexpression of transgenic IGF-I, probably not paralleled by a concomitant increase in IGF-BP2, the possibility exists that high levels of free IGF-I exert an inhibitory action on the lactotrophs. It is well-established that IGF-I exerts a potent negative feedback on somatotropic cells [20-22]. Since lactotrophs and somatotrophs have a common origin and share a number of physiologic features, it seems conceivable that high pituitary concentrations of free IGF-I could have an inhibitory action on lactotropic cells. Clearly, further work is necessary to clarify this matter. 


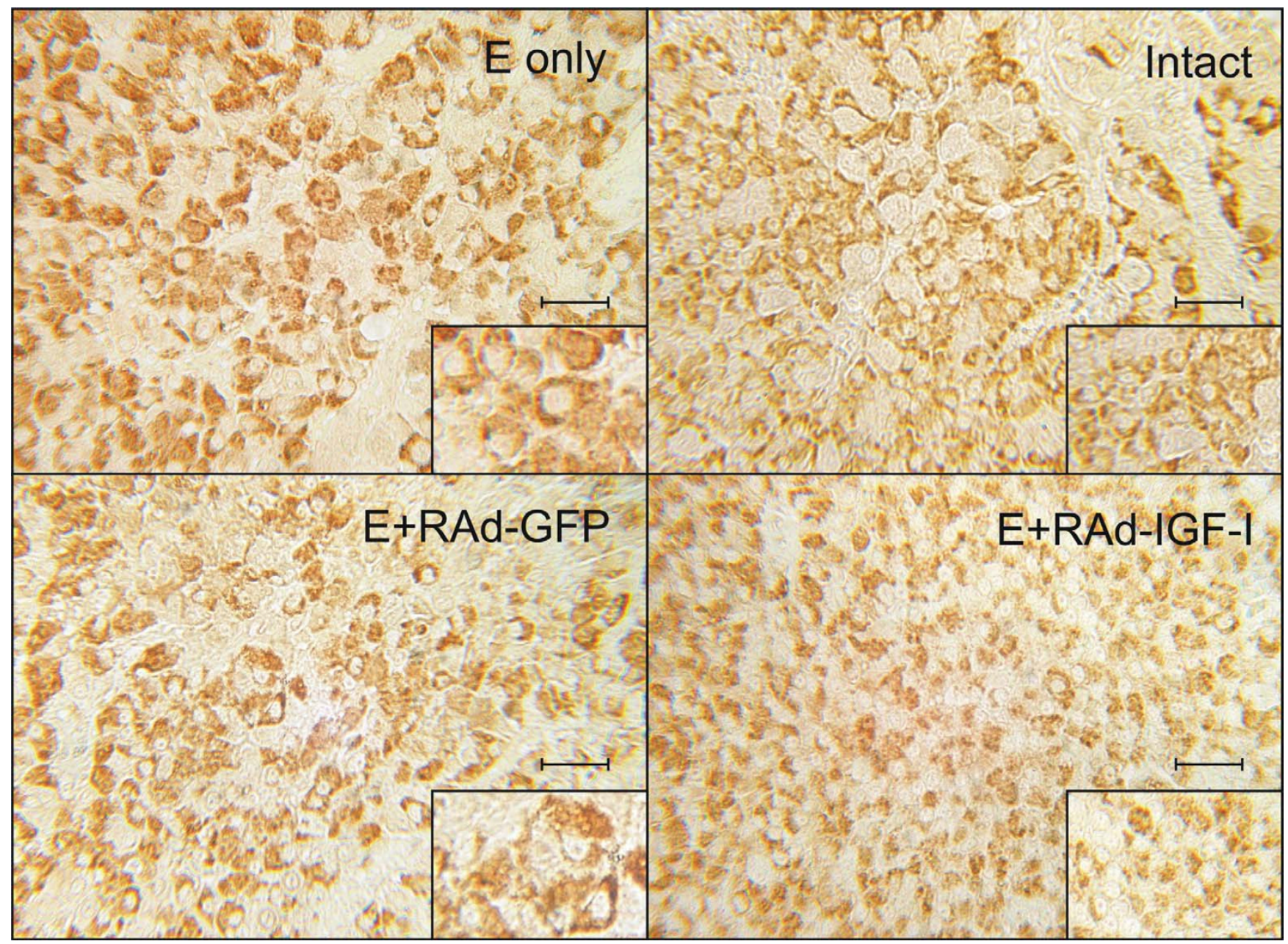

Figure 2

Effect of IGF-I gene therapy on lactotropic cells of pituitary adenomas. Representative fields of specifically immunostained PRL-cells in the pituitary gland of an intact (Intact) rat, an animal treated with estrogen for 4 weeks (E only), and animal receiving estrogen for 4 weeks and RAd-GFP during the last experimental week (E + RAdGFP) and an animal receiving estrogen for 4 weeks and RAd-IGF-I during the last experimental week (E + RAd-IGF-I). Insets. Higher magnification views of the specimens. EnVision system peroxidase. Bar: $25 \mu \mathrm{m}$. Inset: $12.5 \mu \mathrm{m}$.

We conclude that IGF-I gene therapy constitutes a potentially useful intervention for the treatment of prolactinomas and that bioactive peptide gene delivery may open novel therapeutic avenues for the treatment of pituitary tumors.

\section{Methods}

\section{Adenoviral vectors}

RAd-IGFI

A recombinant adenoviral (RAd) vector harboring the rat IGF-I gene (kindly donated by Dr. Peter Rotwein, Oregon Health Sciences University) was constructed in our laboratory by a variant of the two plasmid method employing the AdMax ${ }^{\circledast}$ plasmid kit (Microbix, Ontario, Canada) [23]. Briefly, the cDNA coding for rat IGF-I gene (obtained from the mRNA for the IGF Ib precursor form [24]) was excised from plasmid pBluescript KS, subcloned in pCA14 and inserted in the multiple cloning site (MCS) of shuttle pDC515 which contains an expression cassette consisting of the mouse cytomegalovirus promoter (mCMV) and the simian virus 40 (SV40) polyadenylation signal, immediately upstream and downstream to the MCS, respectively. The second plasmid of the kit, the genomic plasmid pBHGfrt(del)E1,3 FLP, consists of the entire genome of adenovirus 5 (Ad5), containing deletions in the regions E1 and E3. In cotransfected HEK293 cells, FLP recombinase is readily expressed and efficiently catalyzes the site-directed recombination of the expression cassette of pDC515 into pBHGfrt(del)E1,3 FLP, thus generating the genome of the desired recombinant adenoviral vector, RAd-IGF-I (Fig. 


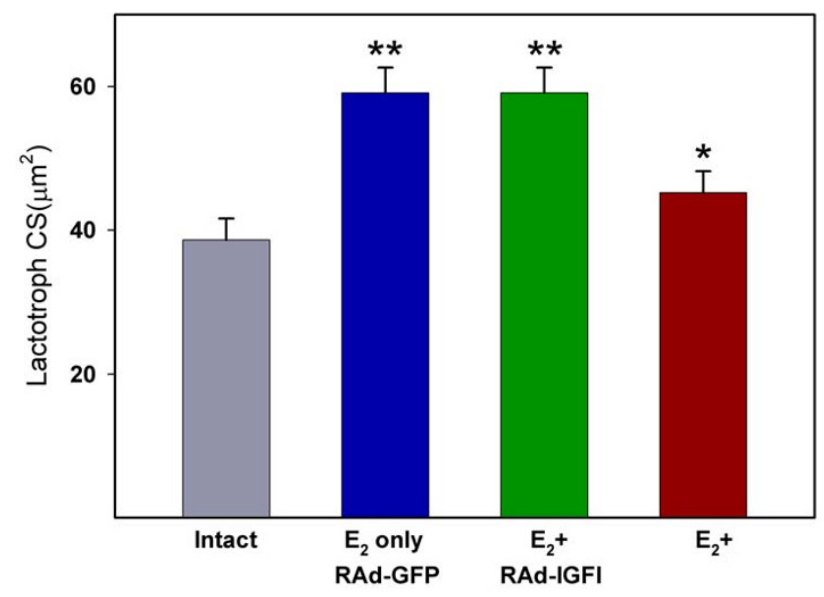

Figure 3

Effect of IGF-I gene therapy on lactotropic cell size. Lactotroph cell surface (CS) in the pituitaries of animals submitted to no treatment (intact), control treatments ( $E_{2}$ only and $E_{2}+$ RAdGFP) or IGF-I gene therapy $\left(E_{2}+\right.$ RAd-IGF-I).

Columns represent mean values whereas bars over columns represent SEM values. Five pituitaries per group were assessed. Asterisks indicate a highly significant difference from the intact group.

6). The newly generated RAd was rescued from HEK293 cell lysates and plaque purified. It was further purified by ultracentrifugation in $\mathrm{CsCl}$ gradient. Final virus stocks were titrated by a serial dilution plaque assay.

\section{RAd-(GFP/TK)fus}

An adenoviral vector termed RAd-(GFP/TK)fus, or RAdGFP for short, was constructed in our laboratory following the general procedures outlined above and was used as a

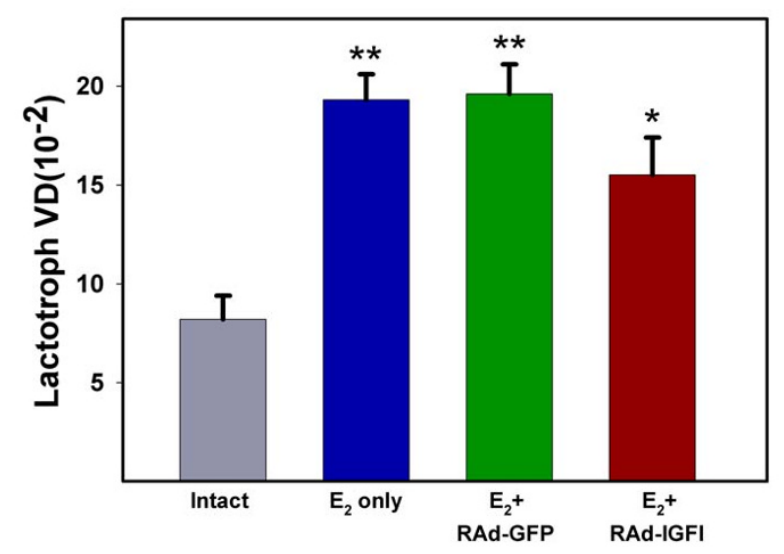

Figure 4

Effect of IGF-I gene therapy on lactotropic volume density (VD). Data correspond to the pituitaries of the same animals shown in Fig 3. Details are as in Fig. 3.

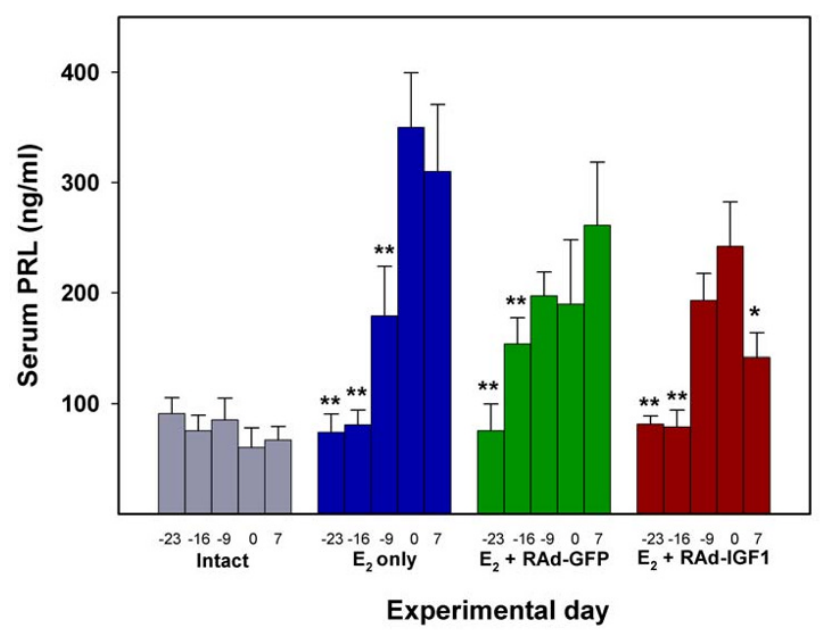

\section{Figure 5}

Effect of IGF-I gene therapy on serum PRL levels. Serum PRL was measured in blood samples serially taken from Experimental day -23 to Experimental day 7. The number of rats used was 5 for all groups except for group $E_{2}$ + RAd-IGF-I where 7 animals were assessed Asterisks indicate significant differences from serum PRL on experimental day 0 (vector injection); *: $P<0.05$; **: $P<0.0$ I. Other details are as in Fig. 3

control vector in the gene therapy studies. The vector harbors a hybrid gene encoding the Aequorea victoria enhanced green fluorescent protein fused to herpes simplex virus type 1 thymidine kinase (GFP/TK)fus (a kind gift from Dr. Jacques Galipeau, McGill University, Montreal, Canada). This hybrid gene is driven by the mouse CMV promoter. The vector was expanded in 293 cells and purified and titrated as indicated above.

\section{Animals}

Young female Sprague-Dawley rats were housed in a temperature-controlled room $\left(22 \pm 2^{\circ} \mathrm{C}\right)$ on a $12: 12 \mathrm{~h}$ light/ dark cycle. Food and water were available ad libitum. All experiments with animals were done following the Animal Welfare Guidelines of NIH (INIBIOLP's Animal Welfare Assurance No A5647-01).

\section{Experimental design for in vivo IGF-I gene therapy}

At experimental day -23 all animals but those of the intact group, were subcutaneously implanted a silastic capsule filled with $17-\beta$ estradiol. Small blood samples $(0.4 \mathrm{ml})$ were taken from the tail veins of all rats on experimental day $-16,-9,0$, day +2 and day +7 for PRL assay. On experimental day 0 , some of the rats received bilateral $1.5 \mu \mathrm{l}$ intrapituitary injections containing $3 \times 10^{9}$ plaque forming units (pfu) of either RAd-GFP or RAd-IGF-I, respec- 


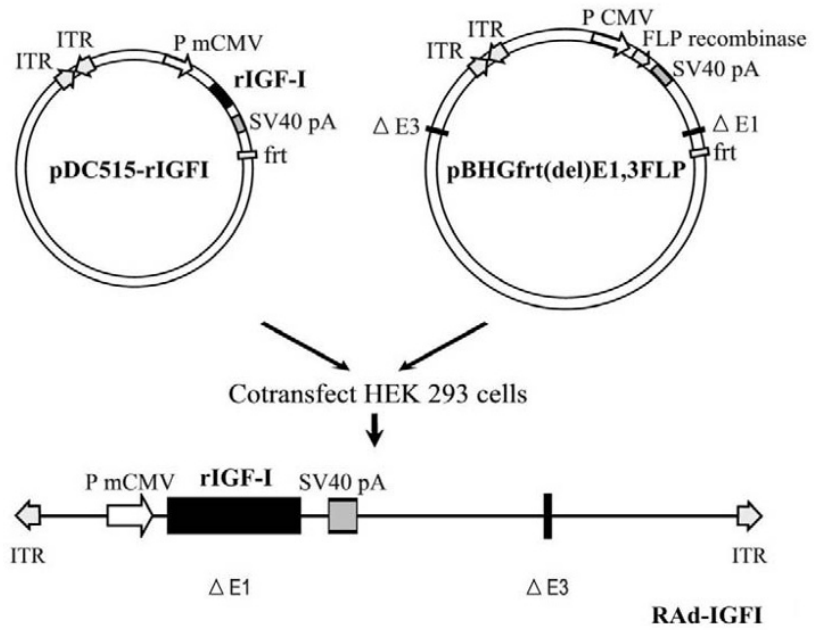

\section{Figure 6}

Diagrammatic representation of the procedure used to construct RAd-IGF-I. An expression cassette containing the rat IGF-I cDNA (form B) flanked by the $\mathrm{mCMV}$ promoter (PmCMV) and the SV40 polyadenylation signal (SV40pA), upstream and downstream, respectively, was inserted in the shuttle vector pDC5I5. Subsequently, pDC5I 5 and the genomic plasmid pBHGfrt(del)EI,3 FLP (which consists of the entire genome of adenovirus 5 (Ad 5), containing deletions in the regions $\mathrm{EI}$ and $\mathrm{E} 3$ ) were cotransfected in permissive HEK 293 cells. Enzyme-directed recombination occurred in cotransfected cells, giving rise to RAdIGFI. frt, recognition element for the yeast FLP recombinase; ITR, inverted terminal repeats; $\Delta \mathrm{I}$ and $\Delta 3$ : deletions in the Ad 5 genome.

tively. For this purpose, rats were anesthetized with injection of ketamine hydrochloride $(40 \mathrm{mg} / \mathrm{kg}$, i.p.) and xylazine ( $8 \mathrm{mg} / \mathrm{kg}$, i.m.), and placed in a stereotaxic frame. In order to access the pituitary region, the tip of a 26 gauge needle fitted to a $10 \mu$ l syringe was brought to the following coordinates relative to the bregma: $5.5 \mathrm{~mm}$ posterior, $9.6 \mathrm{~mm}$ ventral and $0.7 \mathrm{~mm}$ right and left [25]. One week after intrapituitary injection rats were killed by decapitation. Pituitaries were immediately dissected, fixed and processed for routine histological studies.

\section{Immunohistochemistry}

Stated in brief, pituitary tissues from 5 animals of each group were fixed in Bouin's fluid and embedded in paraffin. Serial sections of $4 \mu \mathrm{m}$ were obtained at different levels of the blocks following a ventral-to-dorsal sequence. The sections were immunostained, and then incubated for $1 \mathrm{~h}$ at room temperature with the anti-PRL primary antiserum (murine, Dako, CA, USA), diluted 1:100. Thoroughly washed sections were then treated for $30 \mathrm{~min}$ with a ready-to-use EnVision reaction system (Dako, CA, USA). The peroxide-sensitive chromogen was diaminobenzidine. In all instances, the specificity of the primary antise- rum was monitored either by observing its ability to block the immunocytochemical reaction after its preabsorption with an excess of the related antigen or by its replacement with normal rabbit serum or phosphate-buffered saline [26].

\section{Image analysis}

Morphometry was performed as reported in detail previously [27]. Measurements of pituitary cells were made by means of an image-analysis system (Imaging Technology, Optimas 5.2). The immunostained lactotrope cells and the reference area (RA) were analyzed in each field on an average of ten micrographs taken from two levels (e.g. a and $\mathbf{b}$ ) in the groups studied. These measurements were recorded and processed automatically and the following parameters subsequently calculated: volume density (VD $=\Sigma$ cell area/RA) and cell size (CS) (the mean of individual cell area, expressed in $\mu \mathrm{m} 2$ ). Reference area (RA) represents the adenohypophyseal (pars distalis) area scanned, in which pituitary PRL cells were scored. Then, with the sum $(\Sigma)$ of the individual areas (A), referred to as RA, we obtained volume density (VD), which indicates cell mass according to a generally accepted concept.

\section{Hormone assays}

Serum levels of PRL were measured by a specific radioimmunoassay using the rat materials provided by Dr. A. F. Parlow, Pituitary Hormones and Antisera Center, UCLA Med. Center, U.S.A. Iodination grade hormones were radiolabeled by the Iodo-Gen ${ }^{\circledR}$ method and purified on PD-10 Sephadex ${ }^{\circledast}$ G-25 M columns (Pharmacia, Uppsala, Sweden) equilibrated with $0.01 \mathrm{M}$ phosphosaline, $\mathrm{pH}$ 7.6. A $1 / 10$ goat anti-rabbit IgG in $0.9 \% \mathrm{NaCl}$ was used to separate bound from free hormone. Serum concentrations of PRL were expressed in terms of NHPP rPRL RP-3.

\section{Statistical analysis}

The one way analysis of variance (ANOVA) were used to evaluate group differences. Tukey's method was chosen as a post hoc test. In Figs. 3 and 4 pair comparisons were made between intact and each of the other experimental groups. Also, RAd-GFP vs. RAd-IGF1 pairs were compared in both figures. In Fig. 5 one-way ANOVA was applied to each set of data (intact, E2, etc) and pair comparisons were made between Exptl. Day 0 and each of the other time points.

\section{Authors' contributions}

GMC supervised the morphometric analysis of the pituitaries and made a major contribution to the preparation of the manuscript; $\mathrm{CBH}$ constructed the viral vectors used and performed the surgical procedures; GAC and GML executed the different aspects of the morphometric analysis of pituitaries; MIB carried out the histological procedures involved in this study; GRM performed the studies 
involving immunofluorescence analysis; RGG conceived of the study and participated in its design and coordination as well as in writing the manuscript. All authors read and approved the final manuscript.

\section{Acknowledgements}

The authors are indebted to Mrs. C. Ferese for the technical assistance. This study was supported in part by grant II/MI05 from the National University of La Plata and CIC-PBA to GMC and \# PICTI 3588 from the National Agency for the Promotion of Science and Technology to RGG. RGG and GMC are CONICET and CIC-PBA career researchers, respectively.

\section{References}

I. Daniels GH, Martin JB: Neuroendocrine regulation and diseases of the anterior pituitary and hypothalamus. In Harrison's Principles of Internal Medicine Edited by: Isselbacher KJ, Braunwald E, Wilson JD, Martin JB, Fauci AS, Kasper DL. New York: McGraw-Hill; 1995:189|-1918.

2. Burek JD: Pathology of aging rats Boca Raton: CRC Press; 1978.

3. Lloyd RV: Estrogen-induced hyperplasia and neoplasia in the rat anterior pituitary gland. Am J Pathol 1983, I I 3:198-206.

4. Sarkar DK, Gottschall PE, Meites J: Damage to hypothalamic dopaminergic neurons is associated with development of prolactin-secreting tumors. Science 1982, 21 8:684-686.

5. Shy KK, McTiernan AM, Daling JR, Weiss NS: Oral contraceptive use and the occurrence of pituitary prolactinoma. J Am Med Assoc 1983, 249:2204-2207.

6. Carol N, Lauterbach H, Klinger G, Unger A, Michels W: Prolactin stimulation using the metoclopramide test in females taking oral contraceptives. Zentralbl Gynakol I988, I I 0: I5I5-152I.

7. Fahy UM, Foster PA, Torodo HW, Hartog M, Hull MG: The effect of combined estrogen/progesterone treatment in women with hyperprolactinemic amenorrhea. Gynecol Endocrinol 1992, 6: $183-188$.

8. Ray D, Melmed S: Pituitary cytokine and growth factor expression and action. Endocr Rev 1997, I 8:206-228.

9. Sarkar DK, Hentges ST, De A, Reddy RHR: Hormonal control of pituitary prolactin secreting tumors. Frontiers in Bioscience 1998, 3:934-943.

10. Michels KM, Lee WH, Seltzer A, Saavedra JM, Bondy CA: Up-regulation of pituitary [ I 25I] insulin-like growth factor-I (IGF-I) binding and IGF binding protein-2 and IGF-I gene expression by estrogen. Endocrinology 1993, 132:23-29.

II. Hána V, Haluzik M, Schreiber V: Independence of estrogeninduced pituitary proliferation on local IGF-I mRNA and EGF mRNA expression. Modifying effects of tamoxifen and terguride. Physiol Res 1998, 47:125-31.

12. Kawashima K, Yamakawa K, Takahashi W, Takizawa S, Yin P, Sugiyama N, Kanba S, Arita J: The estrogen-occupied estrogen receptor functions as a negative regulator to inhibit cell proliferation induced by insulin/IGF-I: a cell context-specific antimitogenic action of estradiol on rat lactotrophs in culture. Endocrinology 2002, I 43:2750-8.

13. Ishida M, Takahashi W, Itoh S, Shimodaira S, Maeda S, Arita J: Estrogen actions on lactotroph proliferation are independent of a paracrine interaction with other pituitary cell types: a study using lactotroph-enriched cells. Endocrinology 2007, | 48:3|3|-3।39.

14. Shimon I, Melmed S: Management of pituitary tumors. Annals Int Med 1998, I 29:472-483.

15. Bolognani F, Albariño C, Romanowski V, Carri NG, Goya RG: In vitro and in vivo herpetic vector-mediated gene transfer in the pituitary gland: impact on hormone secretion. Eur J Endocrinol 200I, I 45:497-503.

16. Windeatt S, Southgate TD, Dewey RA, Bolognani F, Perone MJ, Larregina AT, Maleniak TC, Morris ID, Goya RG, Klatzmann D, Lowenstein PR, Castro MG: Adenovirus-mediated herpes simplex virus type-I thymidine kinase gene therapy suppresses oestrogen-induced pituitary prolactinomas. J Clin Endocr Metab 2000, 85: | 296-। 305.
17. Hu N, Gutsmann A, Herbert DC, Bradley A, Lee WH, Lee EY: Heterozygous Rb_I delta 20/+mice are predisposed to tumors of the pituitary gland with a nearly complete penetrance. Oncogene 1994, 9:1021-1029.

18. Riley DJ, Yu A, Lee WH: Adenovirus-mediated retinoblastoma gene therapy supresses spontaneous pituitary melanotroph tumors in Rb+/- mice. Nature Med 1996, 2:1316-1321.

19. Chowen JA, Gonzalez-Parra S, Garcia-Segura LM, Argente J: Sexually dimorphic interaction of insulin-like growth factor (IGF)I and sex steroids in lactotrophs. J Neuroendocrinol 1998, 10:493-502.

20. Morita S, Yamashita S, Melmed S: IGF-I action on rat anterior pituitary cells: effects of intracellular messengers on GH secretion and mRNA levels. Endocrinology 1987, I 2 I:2000-2006.

21. Yamashita S, Melmed S: Insulin-like growth factor-I regulation of growth hormone gene transcription in primary rat pituitary cells. J Clin Invest 1987, 79:449-452.

22. Yamashita S, Ong J, Melmed S: Regulation of human GH gene expression by IGF-I in transfected cells. J Biol Chem I987, 262:13254-|3257.

23. Hereñú $C B$, Cristina $C$, Rimoldi OJ, Becú-Villalobos D, Cambiaggi V, Portiansky EL, Goya RG: Restorative effect of insulin-like growth factor-i gene therapy in the hypothalamus of senile rats with dopaminergic dysfunction. Gene Therapy 2007, I 4:237.

24. Daughaday WH, Rotwein P: Insulin-like growth factors I and II. Peptide, messenger ribonucleic acid and gene structures, serum, and tissue concentrations. Endocr Rev 1988, 10:68-91.

25. Paxinos G, Watson C: The rat brain in stereotaxic coordinates San Diego: Academic Press; 1998.

26. Cónsole GM, Jurado SB, Rulli S, Calandra RS, Gómez Dumm CLA: Ultrastructural and quantitative immunohistochemical changes induced by non steroid antiandrogens on pituitary gonadotroph population of prepuberal male rats. Cells Tissues \& Organs 200I, 169:64-72.

27. Cónsole GM, Jurado SB, Petruccelli $M$, Carino $M$, Calandra RS, Gómez Dumm CLA: Influence of photoinhibition on the morphology and function of pituitary lactotropes in male golden hamster. Neuroendocrinology 2002, 75:316-325.

Publish with Bio Med Central and every scientist can read your work free of charge

"BioMed Central will be the most significant development for disseminating the results of biomedical research in our lifetime. "

Sir Paul Nurse, Cancer Research UK

Your research papers will be:

- available free of charge to the entire biomedical community

- peer reviewed and published immediately upon acceptance

- cited in PubMed and archived on PubMed Central

- yours - you keep the copyright
BiolMedcentral 